\title{
En oplevelse af oplysning: fornuft og følelse $i$ erindringen om Dybbøl og 1864
}

MAds DAugbJerG*

Title: Experiencing enlightenment: reason and emotion in the memory of Dybbøl and 1864.

Abstract: At the historical battlefield of Dybbol in southern Denmark, the Danish defeat at the hands of the Prussian army in 1864 is commemorated. Focusing on visitors' practice at two widely different institutions devoted to the telling of the Dybbol story, the article analyses the relationship between rational enlightenment and sensuous experience in the interpretation of war heritage. Scott Lash's idea of a 'second modernity' is utilised in criticising a conventional and narrow conception of modernity characteristic of much museum theory, exemplified here by the work of Tony Bennett. Subscribing, in contrast, to an understanding of modernity which stresses visitors' sensations and experiences, the article argues that people appropriating heritage draw upon reason as well as emotion: visitors demand an 'experience of enlightenment.'

Key words: Memorials, modernity, war heritage, Dybbøl, visitor studies.

På en stentavle sat udenfor Dybbøl Mølle, en halv times kørsel nord for den dansk-tyske grænse, finder man inskriptionen:

Tvende gange skudt i grus

Atter rejst som møllehus

Vogter for et mindebo

Selv en bauta dansk og tro

Spejd så langt dit øje naar

Grav ved grav i marken staar

Danske mænd gav livet hen

Troskab holder skansen end
Taaredugget ærekrans

Slaar om Dybbøls navn sin glans

Slægter dør men sproget binder

Fremtid gror af dyre minder

Møllen markerer stedet for den danske hærs afgørende nederlag til den preussisk-østrigske alliance 1864 og tabet af en tredjedel af den danske helstats territorium og to femtedele af dens befolkning. Med sin stormfulde historie præget af gentagne ødelæggelser for fjendens ild og efterfølgende genopbygning er møllen i eftertiden blevet det centrale ikon på den uku- 
34 elige danskhed, som nok kunne angribes men ikke udslettes.

Endnu i dag fremstår den fredede højderyg som indbegrebet af et erindringssted, spækket med monumenter, gravsteder og mindelunde. Så sent som 2006 blev slaget ved Dybbøl kanoniseret som en blandt 29 historiske begivenheder og skikkelser, som alle danske børn skal stifte bekendtskab med i folkeskolen - i selskab med blandt andre Tutankhamon, Columbus og Berlinmurens fald. Dybbøl anses altså stadig for uomgængelig. ${ }^{1}$

Denne artikel vedrører nutidens praksis ved og omkring Dybbøl. Den beskriver og analyserer Dybbøls symbolik, budskaber og natio- nale konnotationer, som de udspiller sig i den daglige formidling og forvaltning af dette vigtige erindringslandskab. Historisk kan man iagttage en række omkalfatringer eller 'metamorfoser' i den måde, stedet fra officielt hold er blevet højtideligholdt på (Adriansen 2007). Sådanne skift er imidlertid sjældent totale opgør med tidligere mindekulturer. Snarere kan man sige, at disse findes som aflejrede lag under nutidens iscenesættelser af Dybbøl.

I artiklens analyse af publikums egen betydningsskabelse på to centrale historieformidlende institutioner argumenteres der for, at nutidens kulturturisters 'erindring' og øvrige praksis er spændt ud mellem to poler, som kan

Kanoner og kanoniseret kulturarv. Det historiske artilleri, som symbolsk vogter flagmasten ved Dybbøl Mølle, er populare legeredskaber for den yngste publikumsgruppe. Foto: Mads Dangbjerg.

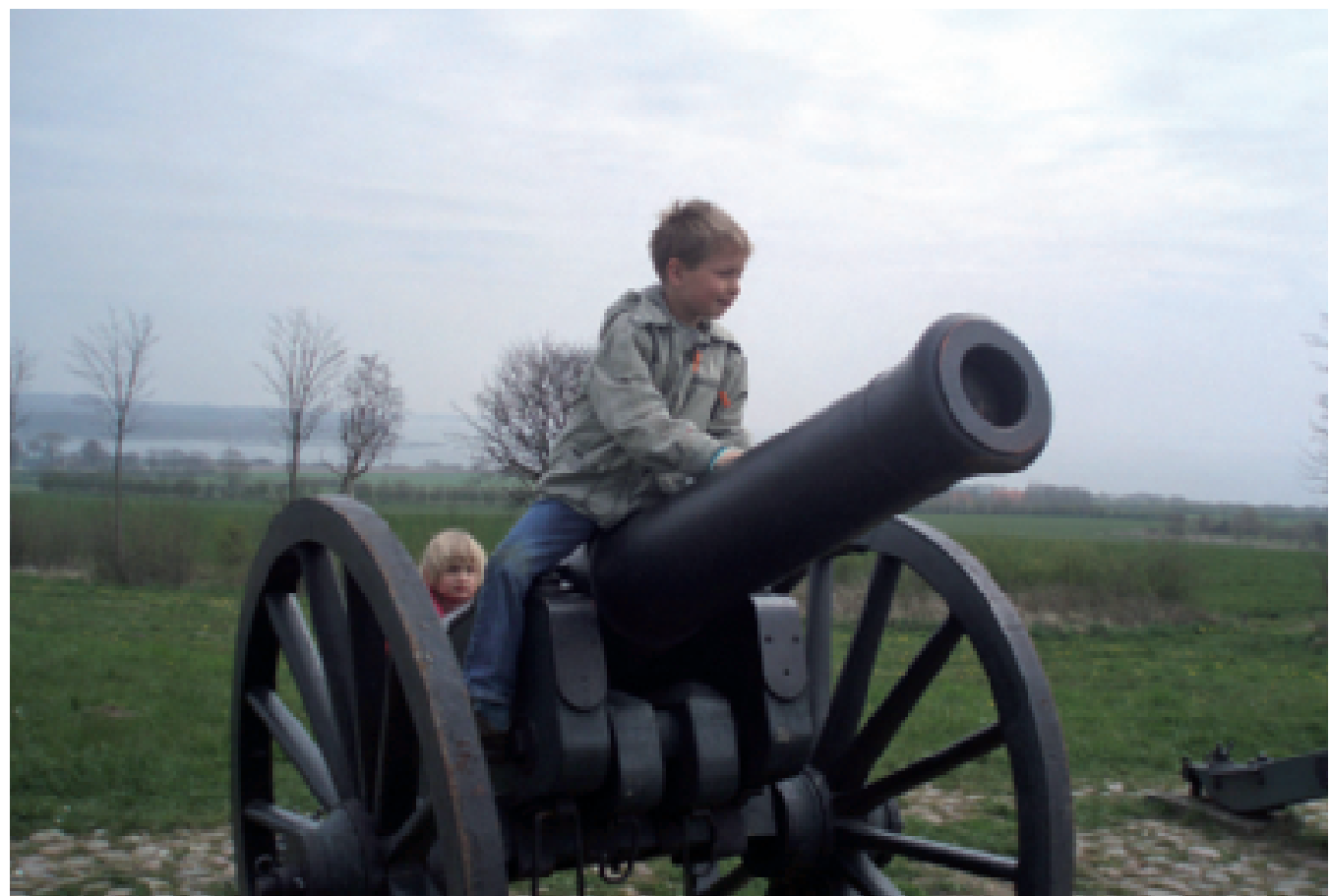


påhæftes mærkaterne oplysning (eller fornuft) og oplevelse (eller følelse). Men på tværs af denne akse, som vedrører kulturformidlingens form, går en anden akse, som handler om formidlingens indhold, herunder især spørgsmålet om stedets nationale dimension. Til slut diskuterer artiklen derfor kort de nationale betydninger, som stadig klæber til symbolet Dybbøl, men som synes under pres fra transnationale og kosmopolitiske dagsordner.

\section{DYBBØL SOM ERINDRINGSSTED - MELLEM DANSK OG TYSK}

Dybbøl skanser er indbegrebet af det, den britiske kulturgeograf Tim Edensor har kaldt et memoryscape:

Memoryscapes comprise the organisation of specific objects in space, resulting from often successive projects which attempt to materialise memory by assembling iconographic form. (Edensor 1997: 178).

Landskabet omkring den gamle slagmark er kendetegnet netop ved spor af forskellige erindringsprojekter, hvori Dybbøl har tjent som en central brik. Ikke overraskende er det især stedets skiftende nationale tilhørsforhold, der har forårsaget de kraftigste ændringer i den henseende. Selvom denne artikel først og fremmest vedrører den nutidige kulturturisme ved og omkring Dybbøl, følger her som ramme for analysen et kort rids over stedets erindringsmæssige historik. ${ }^{2}$

Den danske sejr over tyske tropper ved Dybbøl 5. juni 1848, under første slesvigske krig, indskrev stedet i den nationale historie. Da den danske grundlov året efter blev underskrevet på netop denne dato, blev 5. juni dansk nationaldag. I 1864, da striden om hertugdømmerne Slesvig, Holstein og Lauenburg førte til konflikt med de to største magter i det tyske forbund, Østrig og Preussen, blev Dybbøl den centrale skueplads. Her led den danske hær det afgørende nederlag til den preussiske overmagt, og den danske helstat blev reduceret til en småstat, der måtte slikke sårene og forlade sig på mantraet 'hvad udad tabes, det må indad vindes'.

Dybbøl blev en del af Preussen, og fra 1871 del af det nye store tyske rige under Bismarck. Fra tysk hold fejredes sejren på Dybbøl som første trin i den tretrinsraket, som med de større sejre over Østrig (1866) og Frankrig (1870) førte til Tysklands samling. Et langt større tysk fæstningsanlæg blev bygget i efterkrigsårene på ruinerne af de danske skanser. De spor af skanser og volde, som i dag findes $i$ terrænet ved Dybbøl, stammer primært fra dette tyske projekt.

Desuden oprettede de tyske sejrherrer en række mindelunde og gravpladser for de faldne, både preussere og danske, $i$ årene, der fulgte. Mest markante var imidlertid de to monumentale nygotiske mindesmærker, som rejstes 1872 på Dybbøl og i Arnkil på Als. De to sejrsmonumenter var en torn i øjet på de slagne danskere, for hvem Dybbøl frem for alt stod som en dansk mindelund, men fra tysk hold blev de populære udflugtsmål og grundlagde turismen omkring stedet.

I 1914 fejrede Tyskland 50-årsjubilæet for sejren i 1864 med en stort anlagt mindefest i Sønderborg og på Dybbøl Banke. Hen ved 2000 tyske krigsveteraner deltog, og Kejser Wilhelms bror, Prins Heinrich, lovede dem i en tale at fastholde Dybbøl og Slesvig under tysk styre. Men med udbruddet af Første Verdenskrig samme år, og det tyske nederlag fire år senere, gik det anderledes. Sejrherrerne i verdenskrigen gennemtvang en grænserevision baseret på princippet om folkenes ret til 


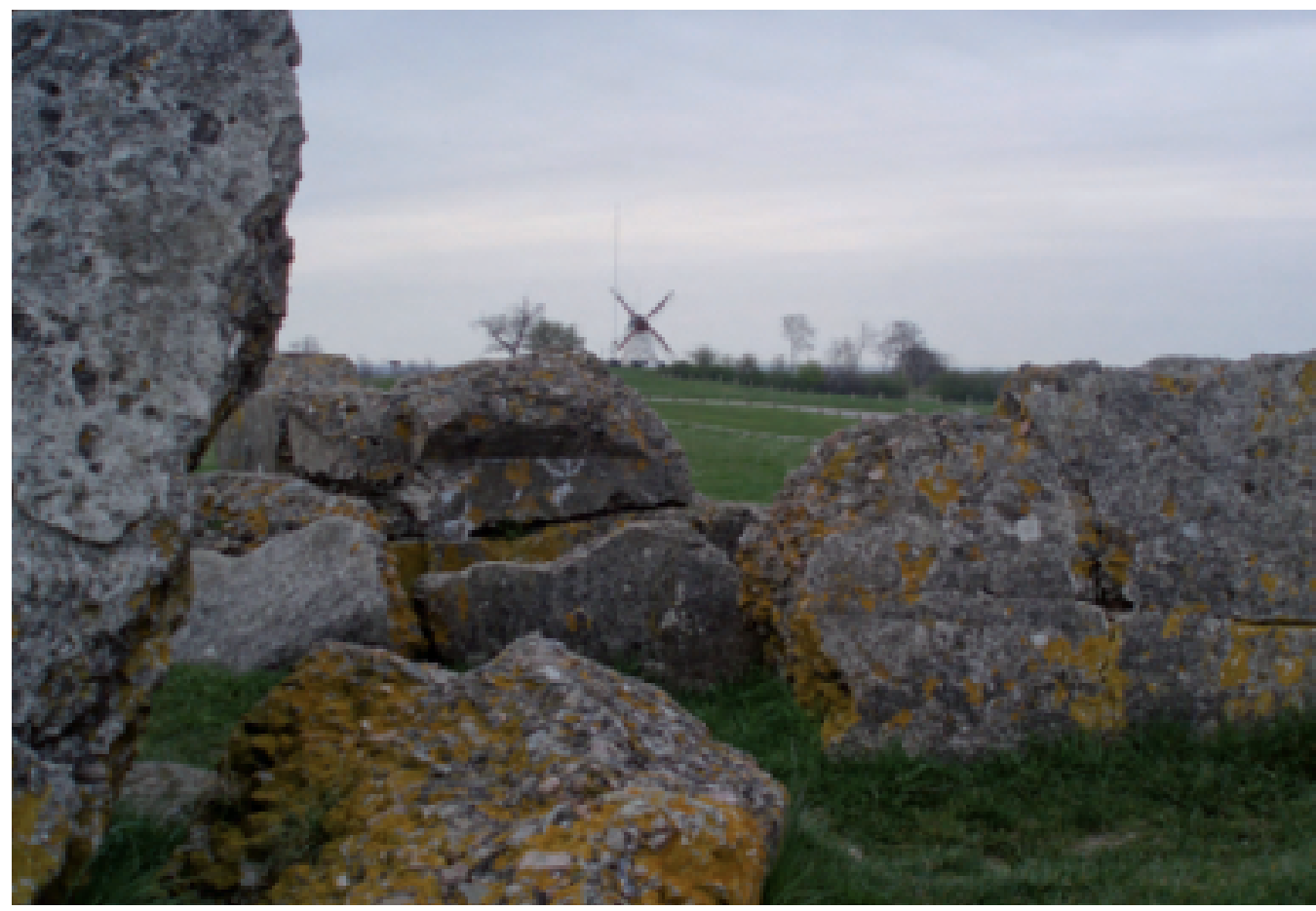

Ruiner fra den danske skanse 4, hvor det valdige tyske sejrsmonument Düppel-Denkmal sprangtes bort i 1945. I baggrunden den ikoniske Dybbøl Mølle, 'tvende gange skudt i grus, atter rejst som mollehus'. Foto: Mads Daugbjerg.

selvbestemmelse, og i 1920 kunne den danske konge, Christian $\mathrm{X}$, ride over den gamle grænse på sin hvide hest. Det, som i Danmark blev kendt som 'Genforeningen' - indlemmelsen af Nordslesvig i kongeriget, og trækningen af den grænse, vi kender i dag - var en realitet.

I årene 1864-1920, hvor Sønderjylland var under tysk styre, blev Dybbøl højtideligholdt fra dansk side som indbegrebet af dansk mod, standhaftighed og offervilje. Selvom beslutningen om at stå fast i 1864 set fra et dansk militærstrategisk synspunkt næppe var nogen klog beslutning, og man kunne have rømmet skanserne inden og sparet tusinder af menneskeliv, tilføjede nederlaget Dybbøl en mytisk status, som en tilbagetrækning ikke kunne have gjort. I litteratur, kunst og brugskunst blev Dybbøl, og især Dybbøl Mølle - 'tvende gange skudt i grus, atter rejst som møllehus' intensivt markedsført som ikon på den danske ukuelighed. Og med Genforeningen 1920 kunne den danske jubel bryde løs. Erindringen om Dybbøl er derfor ikke alene en erindring om det blodige nederlag, men også om kampen for det danske og om triumfen i 1920.

Efter 1920 iværksattes en omfattende fordanskning af Dybbøls kulturlandskab. En landsindsamling førte til opkøb af skanseområdet $\mathrm{og}$ indvielsen af en nationalpark, som statsminister Stauning lovede ville blive beva- 
ret som 'folkets ejendom'. Hundreder af mindesten over faldne danske officerer blev sat op i terrænet i løbet af 1920erne. De to monumentale tyske sejrsmærker stod imidlertid stadig, selvom de fra dansk side blev foreslået udvekslet med Istedløven, det danske sejrsmonument fra den første slesvigske krig, som i 1864 var blevet fjernet fra kirkegården i Flensborg og bragt til Berlin. Disse forhandlinger førte dog ikke til noget, og Dybbøl- og Arnkil-monumenterne stod indtil 1945, hvor de - få dage efter de allieredes befrielse af Danmark - blev sprængt i luften af ukendte gerningsmænd, sandsynligvis tidligere modstandsfolk.

Erindringslandskabet på Dybbøl har altså i bogstaveligste forstand været skueplads for symbolske brud og til tider voldsomme ikonoklastiske aktioner og reaktioner. Og selvom ingen i dag naturligvis personligt kan huske slaget i 1864, indlæses traumatiske minder fra besættelsestiden så at sige i det danske og antityske symbol, som Dybbøl for mange især ældre danskere stadig står som.

\section{Museerne og DET MODERNE}

Museet som institution er et barn af det moderne. Men hvordan skal vi forstå relationen mellem museer og modernitet? Som optakt til publikumsanalysen, der følger, vil jeg nu forfølge den moderne forbindelse og argumentere for, at megen museologisk teori opererer med en forsimplet forståelse af modernitet. Denne artikel er et bidrag til at råde bod på dette forhold og nuancere det publikumsperspektiv, sådanne museumsstudier ofte hviler på.

De europæiske museer, som med Louvre som prototypen voksede frem i kølvandet på den franske revolution, byggede på oplysningstidens idealer og tjente til dannelsen af de nye nationale subjekter og legitimeringer af deres krav på territoriet (Macdonald 2003: 1-2). Med Sharon Macdonalds ord var de offentlige museer steder som

invited people to conceptualise a sense of national or racial difference from others; and to experience their own worlds as relatively and reassuringly governed ones. They helped to convey a sense of both stability and progress. They helped to instantiate a 'scientific', 'objective' way of seeing - a gaze which could 'forget' its own positionedness. They helped to think identities as bounded and coherent. (Macdonald 2003: 5).

De offentlige museer, og i særdeleshed de nye nationalmuseer, var centrale konstituerende og legitimerende institutioner for det nittende århundredes hektiske nationsbygningsprojekter. De understøttede den gryende opfattelse af verden som et system af adskilte nationer, hver med sin distinkte befolkning (ibid.; og se Anderson 1991: 184; Billig 1995: 61). I et sådant verdenssyn var et folk uden et museum at ligne med et folk uden kultur, historie, erindring - kort sagt uden legitimitet (Macdonald 2003: 2-3; Handler 1985).

Der er imidlertid i megen museologisk teori en tendens til at betragte det moderne museum som alene en rationel institution, karakteriseret ved kronologi, orden og en strengt opdragende eller disciplinerende rolle overfor samfundets borgere. Tony Bennetts indflydelsesrige værker (fx 1995; 2004; 2006), som især bygger på læsninger af Michel Foucault, er for eksempel karakteriseret ved en sådan 'rationel' tilgang. Bennett lægger samtidig vægt på museerne som frem for alt visuelle arenaer:

From the early modern period, museums have been places in which citizens - however they might have been defined - have met, conversed, been instructed, or otherwise engaged in rituals through which their 
rights and duties as citizens have been enacted. They have also been, from roughly the same period, primarily institutions of the visible in which objects of various kinds have been exhibited to be looked at. (Bennett 2006: 263).

Hos Bennett anskues museumsbesøget altså som et dannende ritual. Som højmodernitetens rationelle templer 'virker' museerne, ifølge Bennett, ved at disciplinere borgerne og instruere dem i deres borgerlige pligter og rettigheder. Og denne aktivitet antages frem for alt at være af visuel karakter: museet opdrager gennem øjet (Bennett 2004: 160).

Bennetts foucauldianske 'arkæologier' over museumsinstitutionen har stor værdi for forståelsen af deres rolle som ordnende og samlende symbolske institutioner. Tilsvarende overbevisende er Macdonalds påpegning af museernes virke for det kollektive identitetsarbejde og de nye forestillede fællesskaber, omtalt ovenfor (og se Anderson 1991: 178-84). Museerne var og er centrale knudepunkter i denne moderne higen efter orden, fremskridt og homogenitet.

Alligevel er en sådan rationel tilgang til museernes virke i mine øjne utilstrækkelig. Den overser, at 'det moderne' var og er andet end disciplin, orden og borgerrettigheder. Den overser en parallel, og ligeså 'moderne', længpå Sønderborg Slot, fanger publikum $i$ al sin enkelhed. Foto: Mads Daugbjerg.

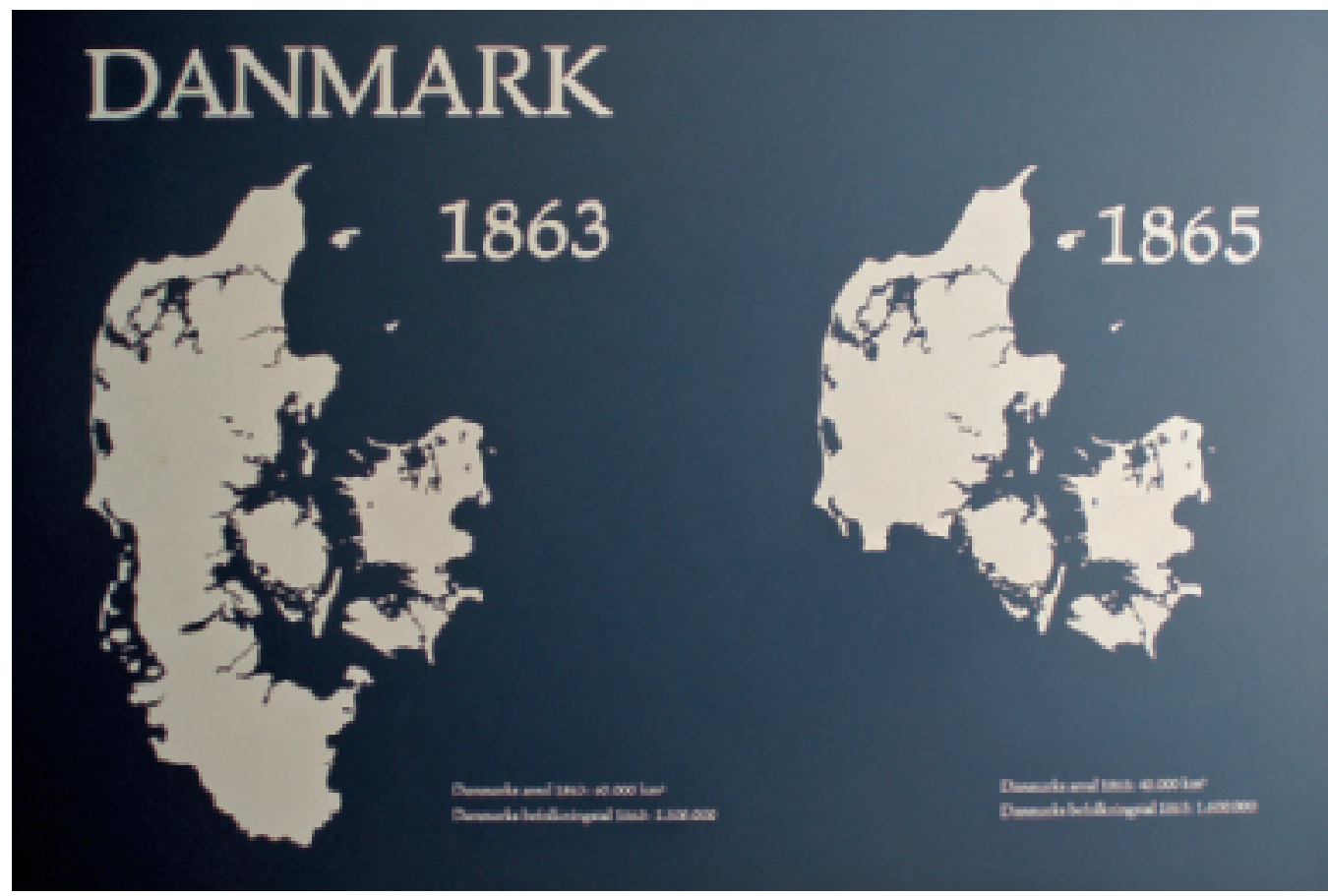


sel efter sanselighed, indre mening og overskridelse af de 'ordentlige' idealer. I en sådan forståelse af det moderne som karakteriseret ved ambivalens - spændt op mellem orden og overskridelse - er jeg især inspireret af den britiske sociolog Scott Lash (1999). I sin idéhistorisk funderede kritik af megen modernitetsteori fremhæver Lash det, han kalder 'den anden modernitet', kendetegnet ved en 'anderledes rationalitet'. Denne anden modernitet knytter sig især til en tysk samfundsvidenskabelig tradition, som igen har sine rødder i romantikken. Den voksede ifølge Lash frem som en reaktion mod en højmoderne rationalitet med rod i oplysningstiden, præget af troen på fremskridt, orden, objektivitet og 'ren' videnskab.

Med andre ord hævder jeg, at en rationel og 'ordentlig' forståelse af museernes rolle, her personificeret ved Bennett (men se også fx Prior 2002; Walsh 1992), kun beskæftiger sig med én side af den moderne tilstand. Den overser eller ignorerer det andet moderne. Udover en snæver forståelse af modernitet er sådanne tilgange typisk karakteriseret ved en udpræget mangel på inddragelse af studier af praksis; af det liv og den betdydningsskabelse, som faktisk udspiller sig i museerne. Antropologerne Richard Handler og Eric Gable hævder ligefrem i deres studie af det amerikanske frilandsmuseum Colonial Williamsburg, at most research on museums has proceeded by ignoring much of what happens in them' (1997: 9, original kursiv). Denne artikel, og det ph.d.projekt, som ligger til grund for den, udgør et forsøg på at rette op på denne udprægede mangel på studier af kulturarvens praktisering.

Netop frilandsmuseerne, som opstod i kølvandet på de internationale udstillinger fra midten af 1800 tallet og frem, udgør måske de klareste eksempler på den moderne dobbelt-

hed. De skandinaviske frilandsmuseer voksede frem som modreaktion mod den uhildede og rene oplysningstankegang. Frilandsmuseernes fortalere anskuede ofte sig selv i opposition til den etablerede museumsverden og hyldede en sanselig, følelsesmættet og romantisk iscenesættelse af fortiden. Ofte var frilandsinitiativerne også båret af nostalgisk-nationale idealer med fejringen af almuekulturen og iscenesættelsen af egnsdragter og traditionelle skikke (se Stoklund 1993; Skougaard 2005). Den bølge af oplevelsescentre og historiske temaparker, som har bredt sig i de seneste årtier i Europa og USA, har eksplicitte rødder i frilandsmuseerne og den 'oplevelsesøkonomi' som de for mere end et århundrede siden indvarslede.

\section{TO INSTITUTIONER: MOD EN OPLEVELSE AF OPLYSNING}

Jeg anerkender altså, at museer handler om orden og fornuft. Men jeg savner en parallel forståelse af deres appel til følelserne; den 'uordentlige' og sanselige længsel, som museerne og den øvrige kulturarvsindustri også rummer - og som bliver tydelig i en analyse af gæsternes praksis. I dette afsnit vil jeg skitsere hvordan den moderne spænding mellem oplysning (eller fornuft) og oplevelse (eller følelse) udspiller sig ved og omkring Dybbøl.

To institutioner i den gamle slagmarks umiddelbare nærhed formidler 1864-historien på meget forskellig vis. Et par kilometer nede ad landevejen huser Museet på Sønderborg Slot grundige udstillinger om de slesvigske krige og grænselandets historie. På mange måder er slotsmuseet præget af en konventionel og kronologisk museal tilgang, baseret på originale genstande udstillet bag glas og understøttet af tætskrevne tekstplancher. I 
40 modsætning hertil tilbyder det nyere Historiecenter Dybbøl Banke, et formidlingscenter beliggende på selve slagmarken, en udpræget multisanselig introduktion til krigen og feltlivet 1864 .

Med andre ord eksemplificerer de to institutioner groft sagt henholdsvis oplysning og oplevelse. Oplysningsmuseet vægter den kronologiske orden, den upartiske og objektive stræben efter fakta, mens oplevelsescentret $s \varnothing-$ ger at ramme gæsternes hele sanseapparat og at formidle de menige soldaters subjektive og ukomplette krigsoplevelser på nært hold. Museet opretholder en fysisk opdeling mellem betragteren og det betragtede (gennem glas- montrer, reb, kustoder) og mellem ekspert og modtager, mens centret opfordrer gæsterne til at involvere sig, røre, føle, improvisere og gå i dialog med personalet.

Men selvom den udgør et godt udgangspunkt, er en sådan principiel fremstilling af de to kulturhuse stereotyp og forenklet. Mine studier af den faktiske daglige interaktion mellem sted, gæster og værter viser for det første, at begge institutioner tilbyder såvel (rationel) oplysning som (romantisk) oplevelse. $\mathrm{Og}$ dernæst, at publikum efterspørger og indlader sig på begge dele: de vil både fornuft og følelse. Snarere end et enten/eller giver det derfor mening at tale om et både-og, eller, vil jeg

Gevarer bag glas. Danske og tyske rifler, ophangt pegende mod hinanden, i 1864-udstillingen på Museet på Sønderborg Slot. Foto: Mads Daugbjerg.

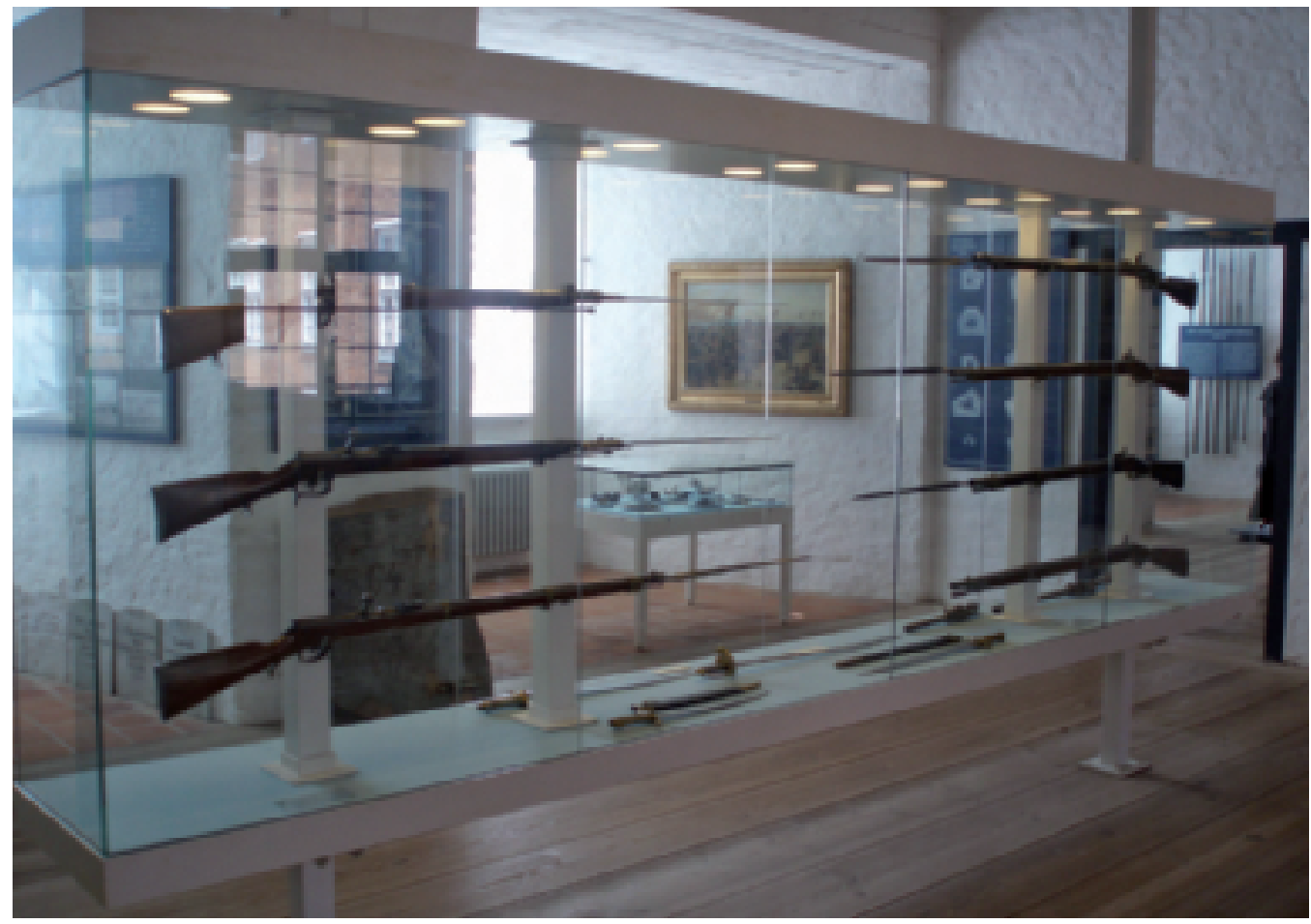


foreslå, om en oplevelse af oplysning. Nedenfor følger nogle eksempler fra mit feltmateriale på denne dobbelthed og vekselvirkning. ${ }^{3}$

\section{MUSEET PA Sønderborg SLOT: OPLYSNING MED INDBYGGET OPLEVELSE}

Museet på Sønderborg Slot er spækket med tekst og glasbeskyttede genstande. Museets krigsudstillinger, som fylder en hel fløj i det firlængede renæssanceslot, er ingen undtagelse: her føres gæsterne kronologisk gennem omtrent hundrede års konfliktfyldt regional historie, centreret om fire krige: de to slesvigske krige (1848-51 samt 1864) og de to verdenskrige. For verdenskrigenes vedkommende koncentrerer museet sig især om disses regionale konsekvenser, $\mathrm{fx}$ den tyske hærs tvangsudskrivning af 6000 dansksindede slesvigere under første verdenskrig. I denne formative periode for det danske folkestyre og det nationale fællesskab, som vi kender i dag, tegnes den danske historie utvetydigt op mod den store trussel fra syd: Tyskland udgør den altdominerende 'anden' på Sønderborg Slot. Centralt i krigsfløjen står krigen 1864 og herunder især slaget ved Dybbøl. Foruden grundige tekstplancher og konventionelle gen-standsudstillinger formidles det kanoniserede slag gennem en skalamodel af slagmarken i størrelsesforholdet 1:1000 og en centralt placeret tavle, der angiver de to hæres styrkeforhold i 1864.

Skalamodellen og statistiktavlen er om noget indikatorer på museet som oplysningsinstitution. Her tilbydes gæsten det store overblik over slaget ved Dybbøl, det kartografiske fugleperspektiv og de nøgternt opregnede fakta. Præcist dette rum blev ofte fremhævet af de danske og tyske gæster, jeg interviewede og fulgte under mit feltarbejde på stedet i 2006.
En gæst svarede fx sådan her, da jeg bad ham 41 om at fremhæve én genstand fra krigsfløjen:

Så vil jeg fremhæve] landskabsmodellen, hvor man har en rumlig fremstilling af Dybbøl Skanser. Hvor man kan se, hvordan skanserne løber på skrå henover Sundeved. Og hvor man kan se tydeligt, hvorfor det krævede en så stor preussisk overmagt at indtage Dybbøl. Den fandt jeg virkelig interessant, hvordan det hele var bygget op, og hvordan det forløb. Og de forskellige tal. (Tysk mand, 64, læge, fra Hamburg) ${ }^{4}$

Det er tydeligvis fornemmelsen af det fugleperspektiviske overblik, der prises her. Denne gæst understregede, i lighed med stort set alle øvrige tyske turister, jeg talte med under mit feltarbejde, at han ikke forbandt nogen særlige nationale følelser med udstillingen om de dansk-tyske konflikter. For ham, sagde han, var der tale om en 'rent teoretisk interesse' for historien. En anden tysk gæst forklarede tilsvarende, at hans interesse var 'den objektive historie' snarere end de følelser, som er knyttet til denne historie (tysk mand, 52, arkitekt, fra Bayern).

Denne tendens til at fremhæve museet som objektiv formidler, som især kendetegner mine tyske gæsteinformanter, men også en del af de danske, støtter opfattelsen af museet som en rationel og objektiv oplysningsinstitution. Idéen om den udenforstående betragter, som kan tilegne sig en objektiv sandhed, binder an til Sharon Macdonalds allerede citerede pointe om, at de tidlige museer understøttede en 'videnskabelig', 'objektiv' synsvinkel - med hendes ord 'et blik som kunne glemme sin egen positionering'. Med henvisning til Timothy Mitchells værk om koloniseringen af Egypten uddyber Macdonald:

This 'way of seeing' crystallised in the nineteenth cen- 


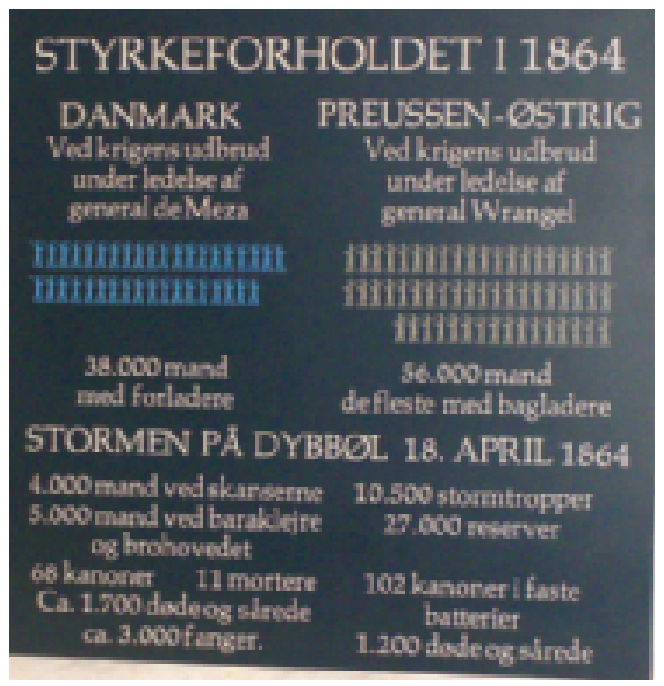

Styrkeforholdstavlen på Museet på Sønderborg Slot. De nogne fakta tilbyder statistisk overblik over slaget ved Dybbol, som den tilstødende landskabsmodel illustrerer grafisk. Foto: Mads Daugbjerg.

tury (Mitchell 1988: 18-23). It entailed a detachment of the viewer - thinking of themselves as outside or above that which was represented. This was coupled with the idea that there was an "imaginary structure" that exists before and apart from something called "external reality" (1988: 21) and that it was possible to find external viewing positions from which the world would appear as ordered and complete. (Macdonald 2003: 3).

Skalamodellen og oversigtstavlen er typiske for den faktuelle, distancerede oplysning, som museet i Sønderborg er rig på. De taler til fornuften, overblikket og forstanden, og antager implicit netop en sådan afstand og objektivitet, som Macdonald omtaler. En anden gæst benyttede på parallel vis modellen til at få overblik over Dybbølslagets gang. Efter sin gennemgang fremhævede han overfor mig styrkeforholdstavlen som et helt centralt element, fordi det ifølge ham 'er imponerende, at tyskerne havde så få tab, når danskerne var $\mathrm{i}$ forsvarsposition' (dansk mand, 26, bankassistent, tidligere underofficer i den danske hær, fra Sorø). Igen betragtes slaget i rationelt fugleperspektiv, og potentielle nationale identifikationer synes at blive skudt i baggrunden til fordel for en generel lovprisning af den tyske strategi og duelighed.

Skalamodellen og styrkeforholdstavlen eksemplificerer altså museet som oplysningsinstitution. Men det er karakteristisk, at den rationelle og regelrette tilgang, som de ovenfor citerede gæster personificerer, suppleres af en anden, mere 'inderlig' eller emotionel relation til det udstillede - også hos disse gæster. Således forklarede den tyske læge, som ovenfor påpegede sin 'rent teoretiske' historiske interesse, mig på et andet tidspunkt i samme interview, at 'med historie spiller affekt altid en rolle, at man kan føle det, emotionelt'. Anledningen var museets montre med udstyret fra en navngiven dansk Dybbølsoldat, som senere gjorde karriere som professor i medicin i København - et faktum som nævnes i udstillingen - og som den tyske gæst genkendte navnet på. Han forklarede mig:

Med historie spiller affekt altid en rolle, at man kan føle det, emotionelt. Jeg fandt for eksempel det enkle uniformsudvalg fra den danske kollega interessant, ham som senere blev professor i medicin i København - ham kendte jeg, jeg har læst noget af ham. Og hans lille udvalg og feltudstyr blev derfor interessant for mig - han var en gammel kollega [griner].

Selv om dette blev sagt med et smil på læben, er det tydeligt, at her er noget andet på spil end ren og objektiv oplysning. I dette tilfælde er der tale om en tilfældig 'kollegial' forbin- 
delse, uden direkte relation til hovedhistorien om Dybbøl og 1864, som gør, at det udstillede opfattes relevant og interessant. Nydelsen af overblik og den 'rent teoretiske interesse', som han tidligere gav udtryk for, afløses altså af eller suppleres med en anden, følelsesmæssig, inderlig og personlig forbindelse. ${ }^{5}$ Samme emotionelle dimension blev taget op, da denne gæst forklarede mig, hvorfor han foretrak at betragte originale historiske genstande frem for kopier. Han fortalte mig om et bestemt historisk dokument, som Henrik IV har underskrevet, og som han havde set under et besøg til Rom:

Og der står man så, og der lå det, dokumentet - og man bliver slået. Altså, for mig er det noget helt specielt at se originalen, fordi det originale, det havde Henriks underskrift, det er hans underskrift. Og det er fascinerende. (...) Jeg kan informere mig teoretisk gennem bøger og billeder, og det gør jeg også. Men at se det originale, det faktiske dokument med underskriften på, det er noget særligt. Og den forbindelse rørte mig.

Vi ser altså her en understregning af den følelsesmæssige og personlige forbindelse som museet også er.

Den unge danske mand, som roste tavlen med de statistiske oplysninger, udviste en tilsvarende emotionel identifikation, da talen faldt på Dybbøls betydning for danskheden. Han sagde, at Dybbøl for ham indikerede 'dansk offervillighed mod overmagten', og at 'vi godt kan nogen gange, selv om vi er små'. $\mathrm{Da}$ jeg spurgte uddybende til de følelser, som symbolet Dybbøl vækkede i ham, sagde han, at han følte 'sorg over generalernes beslutning', for 'det var jo en dødsfælde'. Og at han følte sorg over, at 'her døde så mange danskere'.
Her titter Dybbøls nationale dimension frem. Til forskel fra de tyske turister i mit materiale angav en del danskere en vis, i nogle tilfælde stærk, nationalfølelse knyttet til stedet Dybbøl og 1864. Jeg skal komme tilbage til det komplicerede spørgsmål om den nationale erindring og dens nuværende kår sidst i denne artikel. Her og nu fungerer eksemplet som en yderligere understregning af, at museet ikke blot leverer overblik og oplysning, men at det også vækker følelser og forbindelser hos gæsterne.

Et sidste eksempel fra Sønderborg Slot kan understrege dette og vise, hvordan skalamodellen $\mathrm{i}$ sig selv kan mobiliseres på kreative og ikke-rationelle måder. I dette tilfælde fulgte jeg en dansk familie bestående af en far, en mor og deres treårige datter, gennem et sæt såkaldte video-briller - et sæt plasticbriller, forbundet til et videokamera, som optog gæsternes nøjagtige rute, tidsforbrug og samtaler som her blev båret af faderen i familien. ${ }^{6}$ Gennem sin 16 minutter lange gennemgang af krigsfløjen stoppede faderen på intet tidspunkt for at læse museets tekstplancher. Han og hans hustru talte heller ikke om nogen historiske perioder, hændelser eller krige. I stedet lod de til at betragte de udstillede genstande som kuriosa, 'gamle ting', hvoraf nogle særligt iøjnefaldende fangede deres eller datterens interesse. Ved et grusomt udseende sværd, en faskinkniv fra 1864, udbrød moderen fx 'sikke et mordvåben', og faderen fulgte op: 'få nogen tæsk med den, så er man sgu nok færdig med at spille fandango'. Når talen faldt på krig som det ikke kan undgås i denne fløj af museet - handlede det for disse gæster ikke om nogen bestemt krig, men snarere om krig som fænomen, eller om 'krig i gamle dage'.

Denne ubekymrede og let skøjtende tilgang blev imidlertid afbrudt, da familien ankom til 
44 rummet med skalamodellen. Ansporet af sin kone blev faderen tilsyneladende grebet af en trang til at tyde og forstå modellen. Nedenfor følger et uddrag fra min transskription af videooptagelsen:

Datteren er tydeligvis fascineret af landskabsmodellens bittesmå bygninger og skibe. Hun sidder på den lille hylde, som løber omkring modellen, og kigger op over den omtrent $50 \mathrm{~cm}$ høje plexiglaskant, der beskytter modellen.

Mor: 'De røde og de blå, er det mænd eller hvad?'

Far: 'Det ved jeg ikke. [læser højt fra styrkeforholdstavlen] Danmark ved krigens udbrud... under ledelse af General du-et-eller-andet...'

Mor: 'De blå, det er Danmark. Hvem er så de røde?' Datter: 'Mor, du er de røde.'

Mor: 'Er jeg de røde? Så er du de blå.'

Far: 'Det ved jeg sgu faktisk ikke...' [går tættere på styrkeforholdstavlen]

Datter: 'Mor, jeg er de sølv.'

Mor: 'Nå, ok. Nu er det sådan, at der faktisk ikke er

'Mor, du er de rode!'. Fascination og fantasi som faktor $i$ tilegnelsen af miniatureslagmarken på Museet på Sønderborg Slot. Stillbillede fra videovandring. Foto: Mads Daugbjerg.

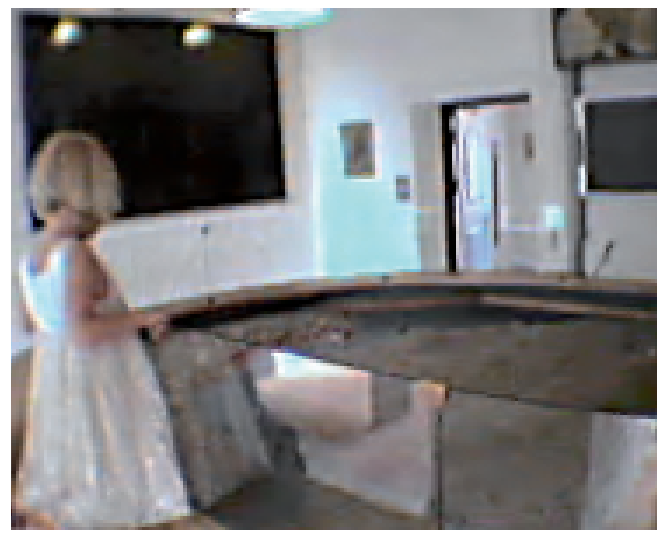

nogen sølvfarver nede i. [Til sin mand:] skal vi gå videre?'

Far: 'Jamen, alt det røde, det må jo høre til et eller andet...' [kigger grundigt på modellen, derefter på landkortene, som hænger ovenover]

Datter: 'Der er kun et lille et [skib].'

Far: 'Ja.'

Datter: 'Er alt det andet vand?'

Mor: 'Ja, det blå, det er vand.'

Far: [prøver stadig at tyde modellen] 'Der er nok... et eller andet sted der...'

Datteren spørger sin mor om noget [kan ikke dechifreres fra videooptagelsen]

Mor: 'Det grønne er landet, markerne og sådan noget.'

Datter: 'Hvor er markerne? Er de grønne?'

Mor: 'Ja.'

Far: [lettere opgivende] 'Ja, jeg forstår ikke et klap af det der. Det er noget med... Der er en hel masse gråt halløjsa, men det røde, det ved jeg sgu ikke... [afbryder sine tolkningsforsøg, kigger ud af vinduet] Nå, vil I med?'

Denne families museumsbesøg handlede ikke om at indsamle historisk viden eller om at ordne verden. Efter sin videovandring fortalte faderen mig, at 'vi vidste intet som helst om hvad der var her, ærlig talt', og at de 'bare skulle have den sidste feriedag til at gå'. Datterens legende tilgang til modellen ('mor, du er de røde') er kendetegnende for familiens generelt ubekymrede og ufokuserede flik-flakken gennem krigsudstillingerne. Men da hans kone spurgte ham til modellens farvede troppemarkører, skiftede faderen tilsyneladende indstilling og bestræbte sig på at fortolke modellen på en 'korrekt' og 'ordentlig' måde. På trods af, at han brugte hen ved to minutter $\mathrm{i}$ koncentreret grublen, var han - lettere irriteret - ude af stand til at identificere, hvem der egentlig skulle forestille at kæmpe mod hvem. 
Han formåede, kan vi sige, ikke at skifte til et rationelt oplysningsblik med succes, ikke mindst fordi han og hans familie i de tilstødende sale ikke havde skænket de mange grundige tekstuelle gennemgange af Dybbølslaget nogen som helst opmærksomhed. Han ankom med andre ord uforberedt til skalamodellen, hvor både han og hans kone fornemmede, at dette rum tilbød et overblik, og at de burde være i stand til at tilegne sig det.

Selvom denne specifikke familie skilte sig ud som særligt ufokuserede og uinteresserede i den historiske kontekst, var mange andre gæster kendetegnet ved en lignende skødesløs og ikkemålrettet tilgang til kulturarven på Sønderborg Slot. For at trække tråden tilbage til Bennett kan man sige, at størstedelen af museumsgæsterne i mit materiale næppe gik på museum for at deltage $\mathrm{i}$ 'rituals through which their rights and duties as citizens [are] enacted' (2006: 263). Snarere udgjorde slottet en romantisk ramme med en uspecificeret historisk atmosfære, som tiltalte dem og tillod dem at føle nogle momentane forbindelser og åbne deres sanser. For sådanne gæster var slotsoplevelsen af større betydning end museumsoplysningen.

\section{HISTORIECENTRET: OPLEVELSE MED INDBYG- GET OPLYSNING}

Ovenfor har jeg skitseret, hvordan museet på Sønderborg Slot, der umiddelbart fremstår som indbegrebet af 'oplysning', også rummer oplevelses- og følelsesmæssige dimensioner. På modsat vis forholder det sig med Historiecenter Dybbøl Banke. I sin grundform er centret

Historiecenter Dybbol Banke, indviet i 1992 som et resultat af private fondsmidler. Centret fremstod isar i sine forste år som et nationalromantisk monument, rejst i indirekte opposition til den etablerede museumsverdens glasmontrer og kustodeprincipper. Foto: Mads Daugbjerg.

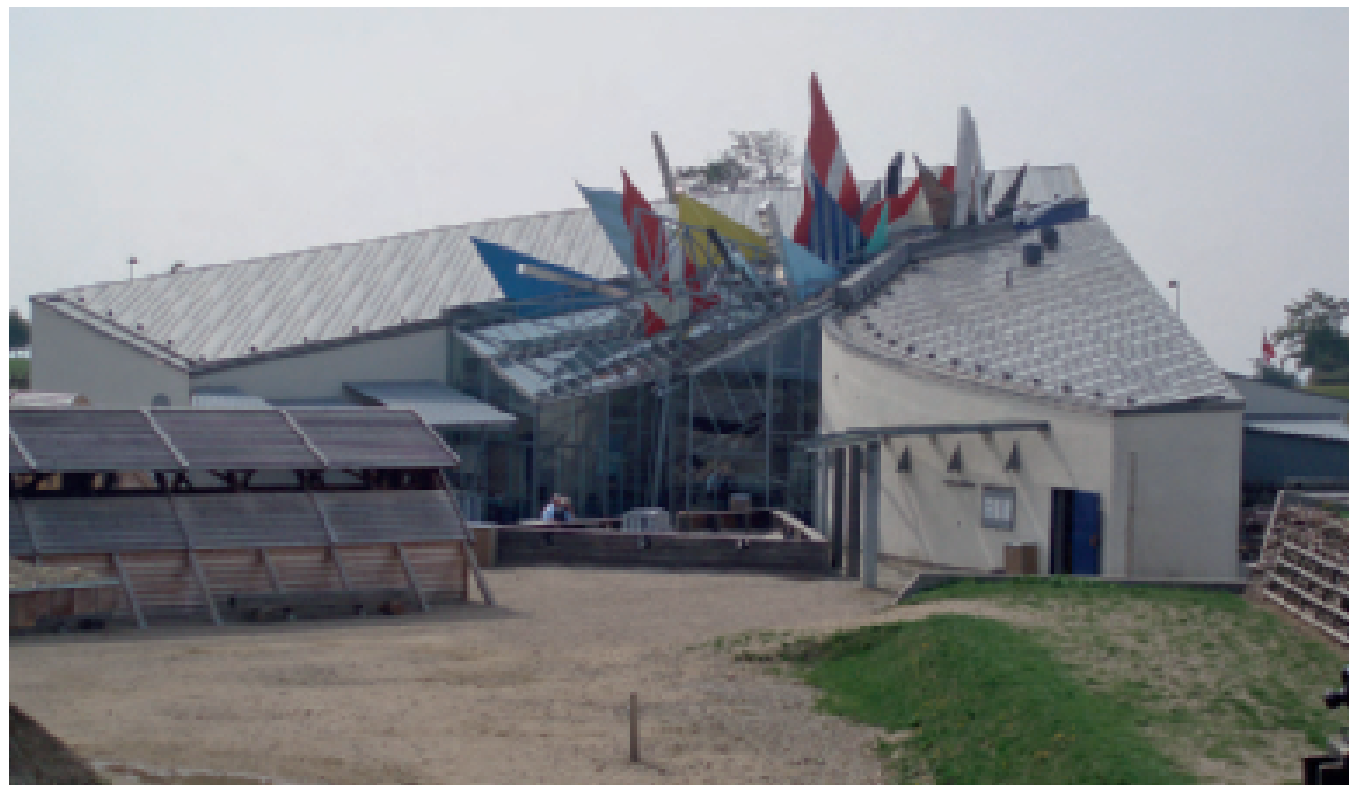


46 klart skabt med henblik på den sanselige oplevelse, og med klar reference til frilandsmuseerne og deres tidligere oprør mod glasmontremuseerne. Men som det vil fremgå, bygger gæsternes oplevelser i centret ikke desto mindre samtidig på en stærk dosis oplysning og en eksplicit arv fra det konventionelle museum. Jeg vil argumentere for, at det netop er denne dobbelthed, som tilfredsstiller flertallet af gæsterne, som ikke er kommet efter den blotte oplevelse, ej heller den rene oplysning - men snarere efter det, jeg vil kalde en 'oplevelse af oplysning'.

Igen vil jeg trække på mit materiale fra en videovandring for at dokumentere denne dobbelte tilegnelse. Igen bæres videobrillen af en familiefar, denne gang en mand i 40erne, ledsaget af sin kone og deres to sønner på 8 og 14. Uddraget nedenfor beskriver familiens besøg i historiecentrets nyligt opførte blokhus, en massiv rekonstruktion, som dominerer centrets gårdsplads. Blokhusene fungerede $\mathrm{i}$ krigen 1864 som beskyttelsesrum for de danske soldater.

Faderen styrer først direkte mod blokhusets åbne dør som for at gå ind, men ændrer så fokus og går helt tæt på tømmerstolperne på husets ydre hjørne. Han rører ved dem og siger: 'Prøv at se noget tømmer, det er banket op af.'

Ældste søn: 'Ja.'

De træder alle fire ind over det høje dørtrin ind i det skyggefulde blokhus, børnene først. I husets venstre hjørne, umiddelbart indenfor døren, står en miniaturemodel af blokhuset og rullebroen, som centret også har rekonstrueret.

Far [om modellen]: 'Så kan man se, hvordan den er bygget op.'

Moderen går dybere ind $\mathrm{i}$ huset og træder op på den trappetrinslignende 'hylde', som løber hele vejen rundt langs de indre vægge, idet hun siger: 'Nå, det var her, de [jeg tror, hun referer til en af centrets historiefortællere] sagde, man skulle gå op og kigge ud [af skydeskårene]. Så passede det med, at granaterne lige kunne komme herind, wrrumm.'

Far [træder også op på forhøjningen og går helt tæt på et skydeskår]: 'Ja. Men det var jo fordi, træet ikke var så tykt her [ved skydeskårene].'

Imens er den yngste søn søgt længere ind i det lange hus og har fundet den kiste med soldaterudstyr, som historiefortællerne benytter, når de viser grupper rundt. Han kalder på sin storebror: 'Rasmus!' Ingen reaktion. Lillebroderen fløjter og kalder så igen, men stadig uden held.

Faderen kigger sig rundt og begynder så at gå så hen mod lillebroderen. Han baner sig vej mellem husets svære støttepiller og loftsbjælker, påpasselig med ikke at støde hovedet imod dem. I baggrunden spørger storebroderen: 'Tror I, de har bygget den i fuld størrelse?'

Faderen når frem til lillebroderen, som nu står bøjet over den lille kiste med udstyr og kigger ned gennem dens glaslåg. Sønnen begynder at remse de ting op, han kan se deri: 'en sabel, en hat, en taske, to geværer'. Faderen giver et samtykkende: 'mmmm', og siger: 'Det der, det er et bagladegevær, garanteret.'

Lillebror: 'Det var sådan et gevær der, vi så dér... [jeg tror, han mener på et tidligere tidspunkt under besøget]. Det er ikke fuldautomatisk.'

Faderen vender sig og går tilbage mod sin kone, som nu studerer miniaturemodellen i hjørnet. Hun mærker på det filt, der er sat på som 'græs' på modellens tag. Imens er den ældste søn trådt op på forhøjningen langs væggen og kigger ud af et af skydeskårene. Hans lillebror følger efter sin far tilbage. I baggrunden høres hans stemme til storebroderen: 'Derovre [ved kisten] ligger der geværer og sabler og sådan noget.'

Moderen føler på filten igen og siger til sin mand: 'Det var meget smart, det der med, at man fandt ud af det der med at putte jord på [blokhusets tag], ikke?'

Næsten samtidig siger den ældste søn, som nu har fået selskab af sin lillebror ved skydeskåret: 'Det, jeg ikke 
forstår, det er... når de så står her, hvad skal de så skyde?'

Faderen kigger op på drengene, og storebroderen stiller sig, som om han holdt et gevær. [Jeg tror, hans undren går på, at blokhuset er placeret midt i den danske skanse, og at kun den indre gård er synlig fra skydeskårene.]

Far: 'Hvis der er nogle, der forsøger at komme op over, ikke?'

Brødrene snakker videre i baggrunden, mens faderen går ned mod blokhusets anden dør i den fjerne ende. De andre følger efter ham. Han stopper ved den åbne dør og vender sig for at vente på de øvrige. Så lyder en svag lyd, som om han banker et par gange på den enormt tykke trædør [dette kan ikke ses på videooptagelsen]. Hans kone siger: 'Åhr, en dør, mand', og han svarer 'ja.' Familien går ud af døråbningen og forlader blokhuset.

Denne videosekvens fra blokhuset giver et godt indtryk af familiens fortolkningsarbejde, som både er af visuel/rationel og af krops-

Overblik gennem fordybelse. Befoling af filten på taget af miniaturemodellen af blokbuset, udstillet indeni den store rekonstruktion af 1864-blokhuset, Historiecenter Dybbol Banke. Stillbillede fra videovandring. Foto: Mads Daugbjerg.

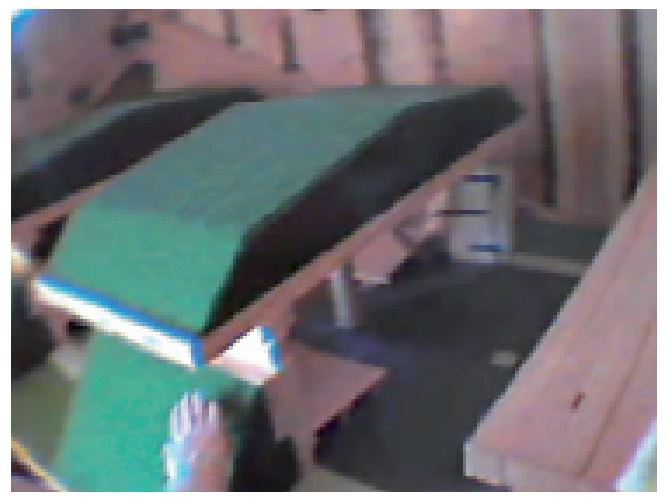

lig/sanselig karakter. Oplevelsen af den suggestive træstruktur er udtalt multisanselig; familien føler sig frem, snuser til det friske træ og finder vej gennem blokhuset, mens de interagerer fysisk med deres omgivelser: de kigger ud af skydeskårene, 'sigter' ud af dem med imaginære rifler og passer på ikke at støde hovederne mod de svære tværbjælker.

Med andre ord taler det rekonstruerede blokhus til mange sanser og fremstår umiddelbart som et mønstereksempel på den oplevelsesmæssige drejning i kulturarvssektoren. Familien improviserer sig frem, leger med genstande og udstillinger og fortolker dem i henhold til information, de har samlet op tidligere under deres besøg. De synes styret af nysgerrighed og oplevelsestrang.

Men jeg vil gerne henlede opmærksomheden på en anden faktor, nemlig miniaturemodellen af blokhuset, som står i hjørnet af rummet. Hvad laver den her? Hvis bestræbelsen med den store rekonstruktion i 1:1 er at skabe en nøjagtig model af et blokhus, som det kunne have taget sig ud før stormen på Dybbøl, giver det vel ikke mening at placere en miniaturemodel inde $\mathrm{i}$ det store blokhus? Der var næppe nogen af de originale blokhuse på slagmarken i 1864, som indeholdt miniaturemodeller af sig selv.

Ikke desto mindre var den lille model en stor succes. Gæsterne flokkedes omkring den, som familien ovenfor, og nød tydeligvis det fortættede overblik, modellen gav dem over centrets byggeprojekt - på samme måde som museumsgæsterne i mine tidligere eksempler nød slottets miniatureslagmark. Historiecentrets model tilbød et indblik i centrets arbejde og det nutidigt udførte, men 'historiske' håndværk, som ligger til grund for rekonstruktionen. Og ingen af de mange gæster, jeg fulgte og talte med i blokhuset, hævede øjen- 
brynene ved synet af en miniaturemodel indsat i et 'rigtigt' (genopført) blokhus. De lod til at finde modellens placering logisk. 'Så kan man se, hvordan den er bygget op', som faderen blot henkastet bemærker ovenfor.

Jeg tolker den lille model som et stykke 'oplysning' indsat i den store ramme af 'oplevelse'. Og familiens rundgang i blokhuset bliver dermed et eksempel på, at gæsterne midt i deres fordybelse, leg og korporlige fornemmelse for stedet også efterspørger det distancerede og rationelle fugleperspektiv. Mit feltmateriale fra historiecentret er fuldt af lignende eksempler på, hvordan man midt i gæsternes sanselige oplevelse finder en gennemgående trang til ind imellem at træe et skridt tilbage og tilegne sig overblik og fakta. Jeg skal nøjes med at fremhæve yderligere ét eksempel, som tydeligt demonstrerer centrets højmoderne oplysningsarv.

På centergrundens højeste punkt er anlagt et udsigtspunkt. Et simpelt rækværk af træ, hvorpå fire slidte tekst- og billedtavler er påsat, fungerer som et klassisk panorama. På plancherne kan gæsterne betragte det landskab, som ligger hinsides centrets volde, og finde information om de skansetomter og andre kendetegn, de kan se i horisonten. Parallellerne til Sharon Macdonalds kommentarer om det særlige blik, som museerne og - beslægtet dermed - masseturismen indvarslede $\mathrm{i}$ det nittende århundrede, er tydelige. Panoramaet tilbyder gæsten det objektive blik på verden og understøtter idéen om adskillelsen mellem subjekt og objekt (Macdonald 2003: 3-4).

Historiecentrets gæster benytter da også panoramaet til sådanne objektive læsninger og til at opnå det store overblik. Men udsigtspunktet inviterer ikke udelukkende til rationelle og disciplinerede læsninger. Nedenfor præsenterer jeg et sidste eksempel fra mit videomateriale fra Dybbøl, som omhandler en dansk families oplevelser ved udsigtspunktet. De trækker ganske vist på den viden, de har samlet op under deres besøg, men de gør det i et tilbagevendende samspil med personlige indfald og kreative tolkninger.

Endnu en gang er der tale om en dansk børnefamilie, og endnu en gang bæres videobrillerne af faderen. Udover sin kone følges han med sin søn på 11 år og sin datter på 7 .

Familien har netop forladt blokhuset og går langs husets ene langside, hvor en tyk træstamme hviler vandret på to træblokke. Datteren ser stammen, peger og

Udblik over fronten. Historiecentrets udsigtspunkt mod vest skriver sig ind $i$ traditionen fra de tidlige panoramaer, som omkring 1900 bredte sig i takt med masseturismens og museernes dyrkelse af det afsondrede men altseende og velinformerede blik på verden.

Foto: Mads Daugbjerg.

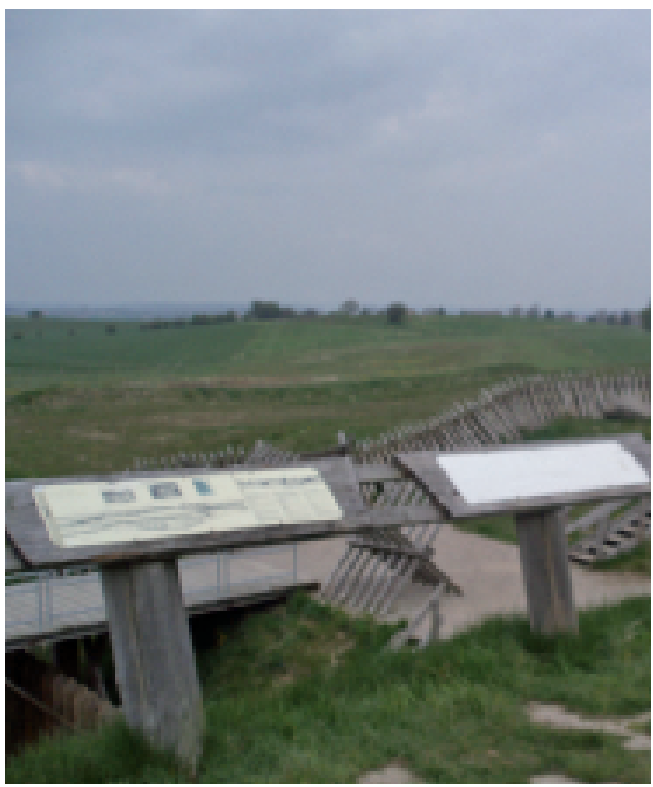


råber: 'Jeg vil op og gå på line!'

Far: 'Så rend du derop.'

Datter: Nej, jeg vil ikke alligevel.'

Far: 'Nå, ok.' Han går videre og siger om træstammen: 'Det er vel bare et stykke træ, de skal til at arbejde på, for at lave dét der [det bearbejdede tømmer til blokhuset] af, vel.

For enden af blokhuset kommer de forbi en savbuk med et bundt sammensurrede pinde [en faskine], og faderen fortsætter: 'Og ligesådan det her, det har vel også været noget, de har...'

Mor: '... stået og vedligeholdt [palisaden med], tror du?'

Far: 'Det tror jeg da, de har stået og vedligeholdt det hele tiden, og repareret på det, når det blev beskudt, ikke også?'

En solid palisade af træ forener blokhuset med porten til skansen. Sønnen hopper op ad de to trin, der fører op til palisaden, kigger ud over kanten, og lader som om han affyrer et gevær henover den. Så hopper han ned igen og løber op ad trappen til udsigtspunktet, fulgt af datteren, så moderen, og til sidst faderen.

Da hun er kommet op på volden, siger moderen: 'Nå, her er der et godt udsyn.'

Søn: 'Tror du, jeg ville kunne ramme en ko herfra?' [refererer til det græssende kvæg på markerne bag historiecentret]

Datter: 'En ko?'

Storebroderen siger noget, som ikke kan høres på videooptagelsen, og går så videre hen mod udsigtspunktet. De øvrige følger efter.

Mor: 'I dag er her jo køer, det var der jo ikke dengang, vel?'

Datter: 'Der er rullebroen!'

Far: 'Der har vi jo rullebroen.'

De taler lidt videre om broen, [her følger et par sekunders ustabilitet i videooptagelsen] mens de går videre. De stopper ved udsigtspunktet.

Mor [læser en af tavlerne sat på rækværket ved udsigtspunktet]: 'En åben skanse, står der, det her det skulle være.'
Søn: 'Far, der er ikke så meget idé i at have en bro dér, for der er en havelåge dér, og så kunne man løbe op dér' [peger mod højre og tegner en cirkel med fingeren op til volden, hvor de står nu]

Far: 'Jo jo. Det her er jo så bare et udpluk af...'

Mor: 'Her står, [læser på tavlen] at dansk skanse 7 var en såkaldt åben skanse, som bagtil ikke var beskyttet af en vold. Det var vanskeligt at forsvare den her skanse. Det kan man godt forstå.'

Far: 'Ja.' Han kigger mod nord, holder en pause på et par sekunder, og fortsætter så: 'Det er klart, de [preussiske angribere] har selvfølgelig udnyttet deres kendskab til skanserne, så de har vidst, at de skulle... det var derfor, de kom her op [peger] over Alssund, og kom ned, den anden vej rundt om [drejer sig mens han udpeger den rute, han mener preusserne har taget]. Og så angriber de lige pludselig stillingerne fra den side, de [danskerne] er svage fra, måske.'

Datteren leger med sin trøje. Det ser ud, som om hun hører efter sin fars forklaringer, men uden at forstå ret meget af dem. Hendes storebror derimod lytter koncentreret og siger 'ja.'

Faderen fortsætter: 'Ikke også? Og når de [preusserne] så overrasker dem [danskerne] ved, at de henleder... med et så kraftigt bombardement på Sønderborg, og på stillingen her, så alt interesse bliver samlet omkring det her punkt - så kan de i fred og ro, mere eller mindre, trække over ovre i Alssund. Det var smart fundet på.'

Søn: 'Ja.'

Datter: 'Se, nu går de over broen!'

Faderen drejer sig og kigger ned mod broen, hvor to personer er på vej over, og siger 'ja.'

Hele familien går tilbage mod trappen, de kom fra.

For denne familie, og faderen i særdeleshed, bliver udsigtspunktet et udgangspunkt for en kreativ og fortløbende tolkning af historien. Der er ikke tale om nogen disciplinerende og objektiverende autoritativ fremstilling, som de udlæser af tavlerne og det medfølgende pano- 


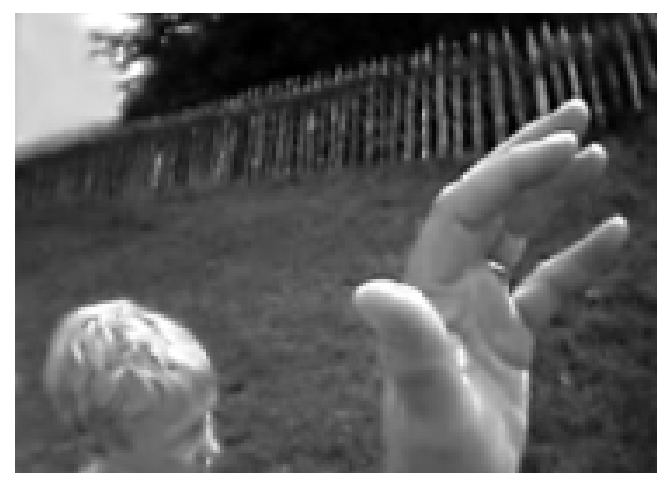

Det var smart fundet på! Sønnike forsøger at folge sin fars sindrige og fantasifulde fabuleringer over slagets gang. Stillbillede fra videovandring. Foto: Mads Daugbjerg.

ramiske perspektiv. Der er ikke tale om 'oplysning' i nogen strengt rationel forstand eller om en Bennett'sk opdragelse af borgerne og deres pligter og rettigheder. Snarere er der tale om præcist det, jeg vil kalde en 'oplevelse af oplysning'.

Familien, og faderen i særdeleshed, synes at improvisere sig frem. Ikke kun i fysisk og sansemæssigt henseende, men også hvad angår en personlig fortolkning og videreudvikling af 1864-historien. I sine udlægninger af krigshistorien, preussernes strategier og danskernes forsvar, trækker faderen på en del af de informationer, han har samlet op under sit besøg på centret. Men han anvender det på sin egen forsøgsvise og fabulerende facon og skaber så at sige sin egen fortælling. Bedømt ud fra kriterier om historisk korrekthed er hans tolkninger ikke meget værd og blander en række forskellige scenarier og episoder sammen. Særligt de snedige preussiske strategier og afledningsmanøvrer er helt hans egne, som han inviterer sin familie med til at gisne om og drive videre i konstruktionen af noget, der ligner en sammenhængende historie.
Denne familiefar var stærkt begejstret for historiecentrets måde at gribe formidlingen an på. Hele hans tur gennem centret var karakteriseret ved denne iver efter at gribe de historiske logikker, men netop ikke som objektive fakta, men som oplevede og medrivende fortællinger, som han selv bidrog til. Stedet befordrede tydeligvis, hos ham, en følelse af kreativitet, nysgerrighed og udforskning. Men det er karakteristisk, at han samtidig med sin kreativt-konstruktive tilgang til historien vitterligt følte sig beriget med information, fakta og oplysning. På et tidspunkt i optagelsen siger han for eksempel til sin kone: 'Jeg ved i hvert fald mere om det her, end jeg har gjort $\mathrm{i}$ mange år. Det kan godt være, jeg har vidst det engang, men det har jeg da lykkeligt glemt. Jeg synes, filmen derinde gav et rigtig godt overblik over situationen på meget kort tid'.

Igen ser vi altså fornemmelsen af kreativitet, fordybelse og selvudforskning gå hånd $\mathrm{i}$ hånd med en følelse af oplysning, orden og viden. Publikum bifalder centrets håndgribelighed og evne til at fremkalde fornemmelser og sanselighed, men de vil også have fakta, overblik og orden. De vil have en oplevelse af oplysning.

\section{HVAD MED NATIONEN? DYBBøL OG DEN KOSMOPOLITISKE UDFORDRING}

Denne artikel omhandler især museumsbesøgets og erindringens form. Men parallelt med den formmæssige bevægelse i retning af mere vægt på sansning og oplevelse ser man ved Dybbøl også et opbrud i formidlingens indhold. Stedets tidligere så entydige nationale dimension udfordres i disse år af en alternativ betydningstilskrivning, der kigger udover nationens grænser. Dybbøl er med andre ord ikke længere alene en 'bauta dansk og tro', 
som stentavlen udenfor Dybbøl Mølle prædiker. I løbet af det seneste årti har man set nye 'kosmopolitiske' dagsordner trænge sig på ved Dybbøl, som ikke længere - i tilhængerne af en sådan udviklings øjne - skal være et dansk mindested, men snarere bør udvikle sig i retning af et interkulturelt forsoningssted.

Det tydeligste eksempel på denne nye symbolik er inddragelsen, siden 2002, af moderne, tysk militær på den årlige Dybbøldag, som højtideligholdes hvert år den 18. april. Parallelt med sorgen over og samlingen omkring de faldne danske søger man nu fra militært hold at favne den tidligere fjende ved retorisk at knytte an til de internationale operationer, dansk og tysk militær deltager i side om side på den globale slagmark.

Også på Historiecentret søger man så at sige at udviske tidligere nationalromantiske dagsordner og billedet af det heroiske danske nederlag. I modsætning til da centret blev født i 1992, lægger man i dag vægt på en balanceret fremstilling, hvor danskernes indsats ikke fremhæves over preussernes, og hvor 'produktet', som sælges, snarere er en universel indsigt i krigens væsen og uhyrligheder end i den specifikke konflikts nationale betydning.

Sådan er i hvert fald de kosmopolitiske principper. Jeg har i en anden sammenhæng (Daugbjerg 2007) kigget grundigere på den ambivalente praksis, disse idealer kastes ud i ved Dybbøl, hvor de strides med konventionelle nationale dagsordner. Resultatet er ofte det, jeg har kaldt 'kosmopolitisk nationalisme', hvor angiveligt universelle, humanitære og forsoningsmæssige værdier og betydninger kombineres med en underforstået national identifikation. Det sker ved, at disse 'universelle' værdier fejres eller brandes som særligt 'danske værdier'. Jeg skal begrænse mig til et eksempel på denne tendens.
Historiens to første Røde Kors-delegerede, en schweizer og en hollænder, som var til stede på slagmarken i 1864, har indtil videre måttet nøjes med en beskeden mindesten udenfor Historiecentret. I disse år florerer imidlertid planer om at lægge større vægt på denne del af historien i form af et decideret Røde Korsmuseum i tilknytning til Dybbøl, som ikke alene skal berette om de to pionerer, men om civile omkostninger, fordrevne og flygtninge, og om humanitært arbejde i global skala. Det er i hvert fald tanken hos en af projektets idémagere, en marketingschef fra en af områdets store virksomheder. Ifølge ham ville et sådant museum kunne markere Dybbøl som 'fredsarbejdets vugge' og Danmark som 'forbilledlig humanitær nation', som han forklarede mig i et interview.

Her har vi den kosmopolitiske nationalisme. Ligesom med inklusionen af de tyske soldater i mindehøjtideligheden er der tydeligvis tale om et brud med tidligere tiders militante og strengt danske heroisme, idet man vil lægge vægt på forsoning og fredsarbejde. Men under denne bekendelse til menneskerettigheder, demokrati og forsoning aner man også en national selvhævdelse: projektet kan markedsføre Danmark som et forbillede, der står vagt om disse værdier. Nationens blodigste plet bliver på paradoksal vis i sådanne, gryende scenarier til et ikon for fred og forsoning, men også for ny, national stolthed.

\section{KONKLUSION: NATIONAL ERINDRING MELLEM} FORNUFT OG FØLELSE

Jeg har i denne artikel argumenteret for, at betydningsdannelse og erindring på historiske steder kan betragtes og analyseres frugtbart som spændt op mellem to poler, som jeg har kaldt 'oplysning' (eller fornuft) og 'oplevelse' 


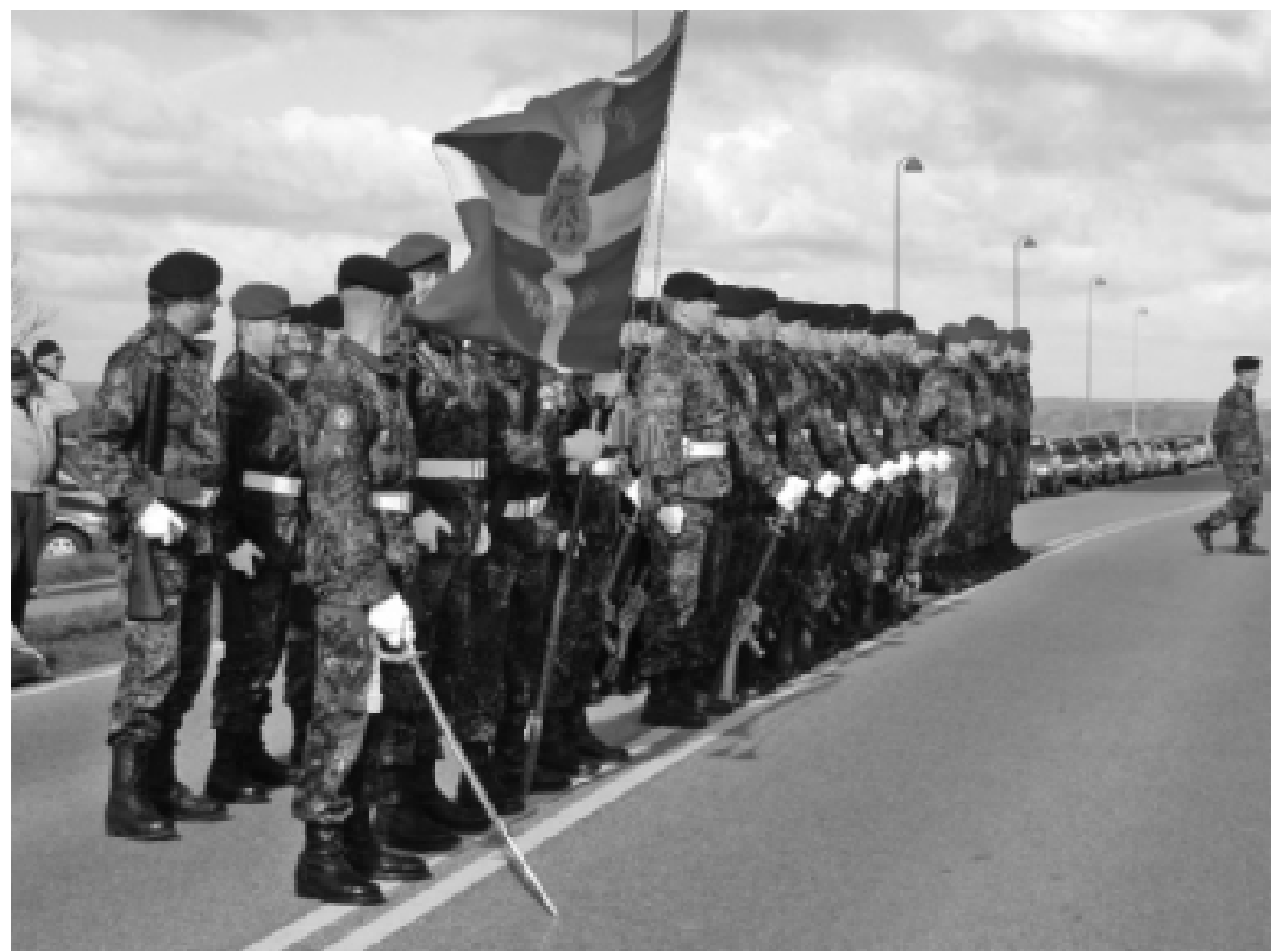

Den ambivalente inklusion. Tyske gester deltager 18. april $2007 i$ den officielle parade ved kransenedlaggelsen for de faldne fra 1864. I forgrunden en dansk, velbevabnet deling fra Sergentskolen i Sønderborg. I baggrunden (med lyse baretter), den mindre tyske enhed, som ikke har lov at bare våben eller fane på dansk jord. Foto: Mads Daugbjerg.

(eller følelse). I min kritik af et historisk og teoretisk perspektiv, som frem for alt opfatter museerne som disciplinerende og opdragende civile institutioner - eksemplificeret ved Tony Bennett - har jeg trukket på Scott Lash's idé om en 'anden modernitet' med et mere romantisk udspring. Museerne 'virker' ikke alene gennem oplysning, men også gennem gæsternes kropslige, personlige og sanselige engagement med udstillinger og steder.

Mine detaljerede eksempler fra Sønderborg Slot og Historiecenter Dybbøl Banke doku- menterer denne dobbelthed. Med dem har jeg søgt at opløse dikotomien mellem oplysningsmuseet og oplevelsescentret og pege på, at gæsterne i begge tilfælde trækker på både fornuft og følelse. At det ikke giver mening at tale om oplysning kontra oplevelse - selvom det ofte er gennem sådanne forestillinger om modparten, museerne og oplevelsesindustrien definerer sig selv - men snarere om publikums behov for en oplevelse af oplysning.

De to geografer Claudio Minca og Tim Oakes har forsøgt at anvende nogle af Lash's idé- 
historiske pointer om det andet moderne i turismeanalysens tjeneste. Parallelt med mine forsøg på at forstå det moderne, og dermed museerne, som kendetegnet både af fornuft og følelse, peger de på turistoplevelsens paradoksale beliggenhed mellem orden og uorden:

Despite our desire for order, and despite relying on an industry that seeks to provide for this desire, travel nevertheless results in a paradoxical experience of ordered disorder. (Minca \& Oakes 2006: 15, original kursiv).

Tanken om en oplevelse af 'ordnet uorden' kan synes obskur. Men i mine øjne beskriver udtrykket, netop ved at påpege denne paradoksale dobbelthed, et centralt element i den faktiske og praktiske oplevelse af kulturarv og erindringen om den. Kulturarvssteder som Dybbøl er på den ene side stramt strukturerende og klassificerende redskaber for forståelsen af vores position i verden, og på den anden arenaer for længsler, forestillinger, følelser og identifikationer, som overskrider klassifikationens stramme struktur. Min analyse af erindringen om Dybbøl er et forsøg på at formidle en sådan dobbelt forståelse af moderniteten og museerne, som ikke alene anerkender paradokserne men fremhæver disse som kernen i det moderne projekt.

\section{NOTER}

1. Rapporten fra det danske Undervisningsministerium kan downloades fra: www.uvm.dk/06/documents/historie_000.pdf

2. Den førende autoritet på Dybbøls symbolske historik er Inge Adriansen, hvis værker (især 1992; 2003; 2007) ligger til grund for mit rids i dette afsnit. For flere detaljer, se Adriansens artikel i nærværende nummer af Nordisk Museologi.

3. Det antropologiske feltarbejde, som ligger til grund for denne artikel, omfattede, foruden observation af og deltagelse i de respektive institutioners daglige praksis gennem et halvt år, 19 kvalitative gæsteinterviews samt 11 såkaldte video-vandringer (som omtales senere). Da de fleste interviews og videooptagelser inkluderede flere gæster, fx ægtepar eller børnefamilier, omfatter mit publikumsmateriale i alt 84 informanter (heraf 67 voksne). Foruden publikumsdelen gennemførtes en række interviews med personale, beslutningstagere og andre 'bagmænd', som ikke behandles i denne artikel.

4. Alle citater fra tyske gæster i denne artikel er gengivet som mine oversættelser fra tysk.

5. Se Bærenholdt 2007 for en diskussion af, hvordan steder opleves gennem 'forbindelser'.

6. Videobrille-metoden er udviklet af lektor Bruno Ingemann, som venligt havde udlånt dem til brug for mit projekt. For diskussion af metoden, se Ingemann 1999; Gjedde og Ingemann 2008.

\section{REFERENCER}

Adriansen, I. 1992. Dybbøl - et dansk og tysk nationalt symbol. Sønderjyske Arbøger: 249-290.

Adriansen, I. 2003. Nationale symboler i det danske rige 1830-2000. Bind II: Fra undersåtter til nation. København: Museum Tusculanums forlag.

Adriansen, I. 2007. Die 12 Metamorphosen von Düppel - eine Kulturlandschaft im Dienst der Erinnerungspolitik. Kieler Blätter zur Volkskunde, vol. 38/39(2006/2007): 23-49.

Anderson, B. 1991. Imagined Communities. Reflections on the Origin and Spread of Nationalism. 2nd revised edition. London \& New York: Verso. Bennett, T. 1995. The Birth of the Museum. History, theory, politics. London \& New York: Routledge.

Bennett, T. 2004. Pasts Beyond Memory. Evolution, Museums, Colonialism. London \& New York: Routledge. 
54 Bennett, T. 2006. Civic seeing: Museums and the Organization of Vision. Pp. 263-281 in: Macdonald, S. (ed.) A Companion to Museum Studies. Oxford: Blackwell.

Billig, M. 1995. Banal Nationalism. London: Sage.

Bærenholdt, J.O. 2007. At forbinde steder - turistoplevelser på farten. Nordisk Museologi. The Journal on Nordic Museums and Museology (2): 5-24.

Daugbjerg, M. 2007. En anden 'anden'. Nationale og globale fællesskaber på Dybbøl Banke. Nord Nytt. Nordisk tidsskrift for etnologi og folkloristik, vol. 102: 65-81.

Edensor, T. 1997. National identity and the politics of memory: remembering Bruce and Wallace in symbolic space. Environment and Planning D, vol. 29: 175-194.

Gjedde, L. \& B. Ingemann 2008. Researching Experiences - Exploring Processual and Experimental Methods in Cultural Analysis. Newcastle: Cambridge Scholars Publishing.

Handler, R. 1985. On having a culture. Nationalism and the preservation of Quebec's Patrimoine. Pp. 192-217 in: Stocking, G.W. (ed.) Objects and Others. Essays on Museums and Material Culture. Wisconsin: University of Wisconsin Press.

Handler, R. \& E. Gable 1997. The New History in an Old Museum. Creating the Past at Colonial Williamsburg. Durham and London: Duke University Press.

Ingemann, B. 1999. "Det er helt vildt!" - Om læsestrategier og reception af en udstilling. Nordisk Museologi. The Journal on Nordic Museums and Museology (1): 155-172.

Lash, S. 1999. Another Modernity, a Different Rationality. Oxford: Blackwell.

Macdonald, S. 2003. Museums, national, postnational and transcultural identities. Museums and society, vol. 1(1): 1-16.

Minca, C. \& T. Oakes. 2006. Introduction: Travelling Paradoxes. Pp. 1-21 in: Minca, C. \& T. Oakes (eds) Travels in Paradox. Remapping Tourism.
Lanham \& New York: Rowman \& Littlefield Publishers.

Mitchell, T. 1988. Colonizing Egypt. Cambridge: Cambridge University Press.

Prior, N. 2002. Museums and Modernity. Art Galleries and the Making of Modern Culture. Oxford \& New York: Berg.

Skougaard, M. 2005. Folkekulturen på museum. Pp. 103-114 in: Ingemann, B. \& A. Hejlskov Larsen (eds) Ny dansk museologi. Århus: Aarhus University Press.

Stoklund, B. 1993. International Exhibitions and the New Museum Concept in the Latter Half of the Nineteenth Century. Ethnologia Scandinavia, vol. 23: 87-113.

Walsh, K. 1992. The representation of the past: $M u$ seums and heritage in the post-modern world. London \& New York: Routledge.

*Mads Daugbjerg, ph.d., er antropolog med speciale $i$ kulturarv, turisme og national identitet. Han har netop forsvaret ph.d.-afhandlingen $A$ site to die for: practices of nationalism at a $\mathrm{Da}$ nish heritage site ved Aarhus Universitet. Han har undervist ved Aarhus Universitet, blandt andet på Center for Museologi, og ved Syddansk Universitet, hvor han for tiden er tilknyttet som ekstern lektor.

Address: Dept. of Anthropology and Ethnography

University of Aarhus

8270 Højbjerg

Denmark.

Phone: +4589424618

E-mail:kunmd@hum.au.dk 